\title{
Substrate Temperature Influenced Structural and Electrical Behaviour of RF Magnetron Sputtered $\mathrm{Ag}_{2} \mathrm{Cu}_{2} \mathrm{O}_{3}$ Films
}

\author{
A. Sreedhar ${ }^{a}$, M. Hari Prasad Reddy ${ }^{a}, \mathrm{~S}_{\text {. Uthanna }}^{a}, \mathrm{U}_{\text {. Martins }}^{b}, \mathrm{E}_{\text {. Elangovan }}^{b, *}$ \\ AND J.F. PIERSON ${ }^{c}$ \\ ${ }^{a}$ Department of Physics, Sri Venkateswara University, Tirupati - 517 502, India \\ ${ }^{b}$ CENIMAT/I3N, Departamento de Ciencia dos Materiais, Faculdade de Ciencias e Tecnologia, FCT \\ Universidade Nova de Lisboa and CEMOP-UNINOVA, 2829-516 Caparica, Portugal \\ ${ }^{c}$ Institut Jean Lamour (UMR CNRS 7198), Department CP2S, Ecole des Mines, Nancy Université \\ 54042 Nancy cedex, France
}

\begin{abstract}
$\mathrm{Ag}_{2} \mathrm{Cu}_{2} \mathrm{O}_{3}$ films were deposited on glass and silicon substrates by RF magnetron sputtering of metallic equimolar $\left(\mathrm{Ag}_{50} \mathrm{Cu}_{50}\right)$ alloy target in $\mathrm{Ar}-\mathrm{O}_{2}$ mixture at different substrate temperature $\left(T_{\mathrm{s}}\right)$ ranging between 303 and $523 \mathrm{~K}$. The effect of $T_{\mathrm{s}}$ on the core level binding energies, structural and electrical properties of the films was systematically studied. The films deposited at room temperature were amorphous. The films deposited at $373 \mathrm{~K}$ were polycrystalline and the crystallinity was increased when the $T_{\mathrm{s}}$ was increased to $423 \mathrm{~K}$. The films deposited at $423 \mathrm{~K}$ and subsequently annealed at $498 \mathrm{~K}$ exhibits single phase $\mathrm{Ag}_{2} \mathrm{Cu}_{2} \mathrm{O}_{3}$. In the case of films deposited at higher $T_{\mathrm{s}}$ of $523 \mathrm{~K}, \mathrm{Ag}_{2} \mathrm{O}$ was decomposed into $\mathrm{Ag}$. The electrical resistivity of the films deposited at $303 \mathrm{~K}$ was $1.2 \times 10^{-5} \Omega \mathrm{cm}$, whereas the films formed at $423 \mathrm{~K}$ and subsequently annealed at $498 \mathrm{~K}$ showed electrical resistivity of $2.2 \times 10^{-3} \Omega \mathrm{cm}$ due to improvement in the crystallinity of single phase $\mathrm{Ag}_{2} \mathrm{Cu}_{2} \mathrm{O}_{3}$.
\end{abstract}

PACS: 71.20.-b, 71.15.Mb, 78.20.Ci, 74.25.Gz

\section{Introduction}

Silver and copper are found together in alloys and some ternary phases of chalcogenides and tellurides. Gomez-Romero et al. [1] first synthesized silver-copper mixed oxide: $\mathrm{Ag}_{2} \mathrm{Cu}_{2} \mathrm{O}_{3}$. It is isostructural with paramelaconite structure $\left(\mathrm{Cu}_{4} \mathrm{O}_{3}\right.$ or $\left.\mathrm{Cu}_{2}^{+} \mathrm{Cu}_{2}^{2+} \mathrm{O}_{3}\right)$ with silver cations located at the $\mathrm{Cu}^{+}$positions. Munoz-Rojas et al. [2] have oxidized the $\mathrm{Ag}_{2} \mathrm{Cu}_{2} \mathrm{O}_{3}$ at room temperature, both electrochemically and by ozone oxidation to achieve the $\mathrm{Ag}_{2} \mathrm{Cu}_{2} \mathrm{O}_{4}$ (or $\mathrm{AgCuO}_{2}$ ). It crystallizes with crednerite structure $\left(\mathrm{Cu}^{+} \mathrm{Mn}^{3+} \mathrm{O}_{2}\right)$ with $\mathrm{Ag}$ cations located at the $\mathrm{Cu}^{+}$positions and $\mathrm{Cu}$ cations at the $\mathrm{Mn}^{3+}$ sites [3]. $\mathrm{Ag}_{2} \mathrm{Cu}_{2} \mathrm{O}_{3}$ finds application as cathode in primary batteries and achieves an average discharge voltage of $2.0 \mathrm{~V}$ [4]. Feng et al. [5] have performed theoretical studies on the electrical and optical properties of $\mathrm{AgCuO}$ and $\mathrm{Ag}_{2} \mathrm{Cu}_{2} \mathrm{O}_{3}$. Pierson et al. [6] have deposited $\mathrm{Ag}-\mathrm{Cu}-\mathrm{O}$ films with different compositions by co-sputtering the composite targets of silver and copper. Petitjean et al. have reported the influence of annealing temperature on the structure of $\mathrm{Ag}_{2} \mathrm{Cu}_{2} \mathrm{O}_{3}$ films formed with $\mathrm{Ag}_{50} \mathrm{Cu}_{50}$ target [7], and the effect of oxygen partial pressure on various properties of $\mathrm{Ag}-\mathrm{Cu}-\mathrm{O}$ films deposited utilizing $\mathrm{Ag}_{60} \mathrm{Cu}_{40}$ target [8]. Uthanna et al. [9] have reported the effect of deposition temperature on the structural, electrical and optical properties of $\mathrm{Ag}-\mathrm{Cu}-\mathrm{O}$

\footnotetext{
* corresponding author; e-mail:

eevan2003@yahoo.co.in; elam@fct.unl.pt
}

films RF magnetron sputtered using the $\mathrm{Ag}_{70} \mathrm{Cu}_{30}$ target. Narayana Reddy et al. [10] have studied the effect of oxygen partial pressure and substrate temperature $\left(T_{\mathrm{s}}\right)$ on the structural, electrical and optical properties of $\mathrm{Ag}-\mathrm{Cu}-\mathrm{O}$ films deposited using $\mathrm{Ag}_{80} \mathrm{Cu}_{20}$ target. In this investigation, thin films of $\mathrm{Ag}_{2} \mathrm{Cu}_{2} \mathrm{O}_{3}$ were deposited by $\mathrm{RF}$ magnetron sputtering of $\mathrm{Ag}_{50} \mathrm{Cu}_{50}$ target at different $T_{\mathrm{S}}$ and studied the effect of $T_{\mathrm{S}}$ on the core level binding energies, crystal structure, surface morphology and electrical properties.

\section{Experimental details}

$\mathrm{Ag}_{2} \mathrm{Cu}_{2} \mathrm{O}_{3}$ films were deposited on glass and $p$-type (111) silicon substrates by RF reactive magnetron sputtering of equimolar silver-copper $\left(\mathrm{Ag}_{50} \mathrm{Cu}_{50}\right)$ target of $50 \mathrm{~mm}$ diameter at various $T_{\mathrm{s}}$ in the range of $303-523 \mathrm{~K}$, at oxygen partial pressure of $2 \times 10^{-2} \mathrm{~Pa}$ and sputtering pressure of $4 \mathrm{~Pa}$. The power applied to the sputter target was $65 \mathrm{~W}$ by using Advanced Energy RF power generator. Thickness of the deposited films measured using Veeco Dektak (model 150) depth profilometer was ranging between $200 \mathrm{~nm}$ and $600 \mathrm{~nm}$. The core level binding energies of the deposited films was analyzed with X-ray photoelectron spectroscopy (XPS). The crystallographic structure of the films was confirmed using a Bruker D8 advanced diffractometer at a fixed grazing angle of $4^{\circ}$ using monochromatic $\mathrm{Cu} K_{\alpha_{1}}$ radiation $(\lambda=1.5406 \AA)$. The surface morphology of the films was analyzed using an atomic force microscopy (AFM). The electrical properties of the films were measured at room temperature 
using four probe techniques in van der Pauw configuration.

\section{Result and discussion}

Figure 1 shows a representative XPS survey scan spectrum of the $\mathrm{Ag}_{2} \mathrm{Cu}_{2} \mathrm{O}_{3}$ film deposited on silicon substrate at $303 \mathrm{~K}$ and oxygen partial pressure of $2 \times 10^{-2} \mathrm{~Pa}$. The spectrum contained the characteristic core level binding energy peaks of silver, copper and oxygen. The core level binding energy peaks observed at about 368 and $374 \mathrm{eV}$ were related to the $\mathrm{Ag} 3 d_{5 / 2}$ and $\mathrm{Ag} 3 d_{3 / 2}$ due to the spin-orbit splitting of the energy levels. The peak observed at about $530 \mathrm{eV}$ was related to core level binding energy of $\mathrm{O} 1 s$. The peaks observed at around 934 and $954 \mathrm{eV}$ were the characteristic core level binding energies of $\mathrm{Cu} 2 p_{3 / 2}$ and $\mathrm{Cu} 2 p_{1 / 2}$, respectively [11]. The chemical composition of the films was determined from the core level binding energy peak areas and sensitive factors of the constituent elements. The chemical composition of the films was maintained as very close to $\mathrm{Ag}_{2} \mathrm{Cu}_{2} \mathrm{O}_{3}$.

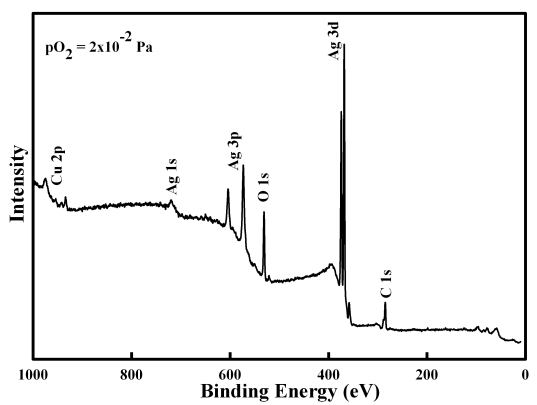

Fig. 1. XPS survey scan of $\mathrm{Ag}_{2} \mathrm{Cu}_{2} \mathrm{O}_{3}$ film deposited at $303 \mathrm{~K}$.

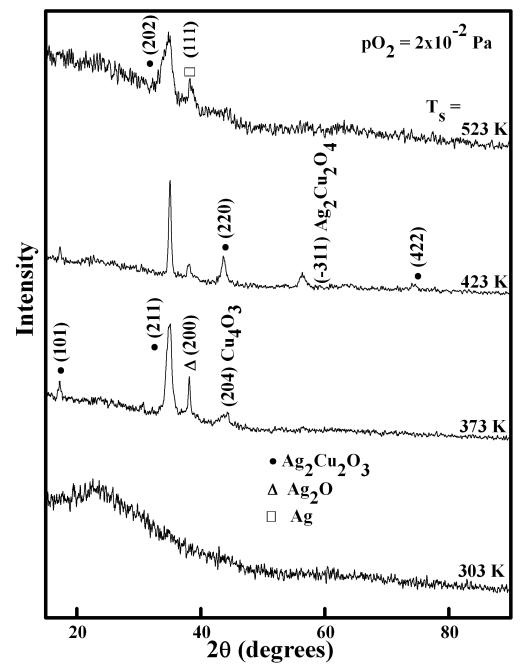

Fig. 2. X-ray diffraction patterns of $\mathrm{Ag}_{2} \mathrm{Cu}_{2} \mathrm{O}_{3}$ films formed at different substrate temperatures.
Figure 2 shows the X-ray diffraction patterns of $\mathrm{Ag}-\mathrm{Cu}-\mathrm{O}$ films deposited on glass substrates kept at different $T_{\mathrm{s}}$. The films deposited at $303 \mathrm{~K}$ were amorphous. The films deposited at $373 \mathrm{~K}$ showed diffraction peaks at diffraction angles $\left(2 \theta^{\circ}\right)$ of $17.28,35.07,38.16$, and $44.28^{\circ}$. The broadening of the obtained diffraction peaks indicates the growth of nanocrystalline films. The peaks observed at $17.28^{\circ}$ and $35.07^{\circ}$ are related to the diffractions from (101) and (211) planes of $\mathrm{Ag}_{2} \mathrm{Cu}_{2} \mathrm{O}_{3}$ [12]. The peak observed at $38.16^{\circ}$ is related to the diffraction from (200) plane of $\mathrm{Ag}_{2} \mathrm{O}$ [13], whereas the peak observed at $44.28^{\circ}$ belongs to the $\mathrm{Cu}_{4} \mathrm{O}_{3}$ phase [14]. It is understood that the films deposited at $373 \mathrm{~K}$ have mixed phase of $\mathrm{Ag}_{2} \mathrm{Cu}_{2} \mathrm{O}_{3}, \mathrm{Ag}_{2} \mathrm{O}$ and $\mathrm{Cu}_{4} \mathrm{O}_{3}$. Further increase in $T_{\mathrm{s}}$ to $423 \mathrm{~K}$ has decreased the intensity of $\mathrm{Ag}_{2} \mathrm{O}$ peak while the $\mathrm{Cu}_{4} \mathrm{O}_{3}$ phase disappeared. An additional peak observed at $56.37^{\circ}$ was related to the diffraction from (311) plane of $\mathrm{Ag}_{2} \mathrm{Cu}_{2} \mathrm{O}_{4}$ [15] and the peaks observed at $43.62^{\circ}$ and $74.04^{\circ}$ correspond to the diffractions from (220) and (422) planes of $\mathrm{Ag}_{2} \mathrm{Cu}_{2} \mathrm{O}_{3}$. The intensity of (101) and (211) diffraction peaks of $\mathrm{Ag}_{2} \mathrm{Cu}_{2} \mathrm{O}_{3}$ was also enhanced due to the improvement in crystallinity of the films. The XRD analysis revealed that the films deposited at $423 \mathrm{~K}$ belong to single phase $\mathrm{Ag}_{2} \mathrm{Cu}_{2} \mathrm{O}_{3}$ with a fraction of $\mathrm{Ag}_{2} \mathrm{Cu}_{2} \mathrm{O}_{4}$ phase. Further increase in $T_{\mathrm{s}}$ to $523 \mathrm{~K}$ has resulted in the formation of films showing a weak diffraction from (211) plane of $\mathrm{Ag}_{2} \mathrm{Cu}_{2} \mathrm{O}_{3}$ and a diffraction from (111) plane of silver due to the temperature induced growth. The films deposited at $423 \mathrm{~K}$ were also subjected to open air annealing at $498 \mathrm{~K}$ for $3 \mathrm{~h}$. The films annealed at $498 \mathrm{~K}$ showed the diffractions from (101), (211), (220) and (422) planes corresponding to the single-phase $\mathrm{Ag}_{2} \mathrm{Cu}_{2} \mathrm{O}_{3}$ films as shown in Fig. 3. The intensity of the diffraction peaks has been enhanced in annealed films, which is presumably due to the improvement in the crystallinity. The crystallite size of the films calculated from the full width at half maximum of (211) reflection is increased from 12 to $20 \mathrm{~nm}$ for the increase in $T_{\mathrm{S}}$ from 373 to $423 \mathrm{~K}$. The crystallite size of the films formed at high $T_{\mathrm{s}}$ of $523 \mathrm{~K}$ was relatively smaller $(7 \mathrm{~nm})$, which is probably due to the decomposition of the films into the metallic silver. The films deposited at $423 \mathrm{~K}$ and annealed at $498 \mathrm{~K}$ exhibited the large crystallite size of $24 \mathrm{~nm}$ that is attributed to the improvement in the crystallinity.

The surface microstructures obtained from AFM analysis indicates that grain size of the films is increased from 42 to $110 \mathrm{~nm}$ for the increase in $T_{\mathrm{s}}$ from 303 to $423 \mathrm{~K}$, which may be related with the improvement in crystallinity. It is understood that the increase in $T_{\mathrm{S}}$ modifies the surface microstructures of the deposited films. The films deposited at $303 \mathrm{~K}$ contained spherical shaped grains, while those deposited at elevated temperatures consisted of grains that are pyramidal in shape. The films grown at $303 \mathrm{~K}$ showed a smooth surface with root mean square roughness $\left(R_{\mathrm{rms}}\right)$ of $\approx 4.6 \mathrm{~nm}$, which is increased to $\approx 20.0 \mathrm{~nm}$ for the increase in $T_{\mathrm{s}}$ to $473 \mathrm{~K}$. The single phase $\mathrm{Ag}_{2} \mathrm{Cu}_{2} \mathrm{O}_{3}$ films obtained from anneal- 


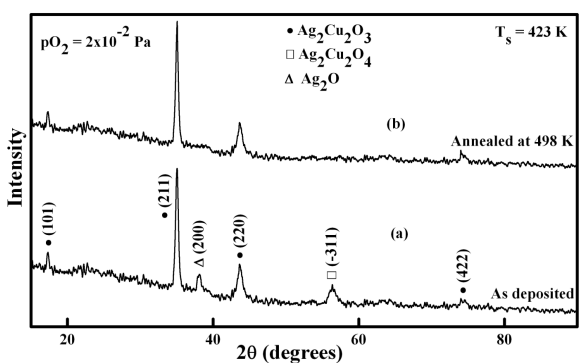

Fig. 3. X-ray diffraction patterns of $\mathrm{Ag}_{2} \mathrm{Cu}_{2} \mathrm{O}_{3}$ films: (a) deposited at $T_{\mathrm{s}}=423 \mathrm{~K}$ and (b) deposited at $T_{\mathrm{s}}=$ $423 \mathrm{~K}$ and post-annealed at $498 \mathrm{~K}$.

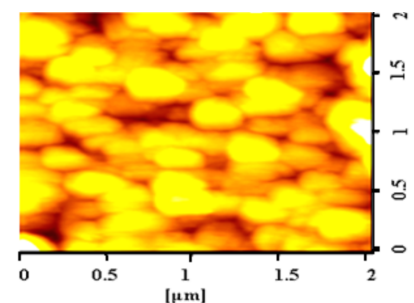
[nm]
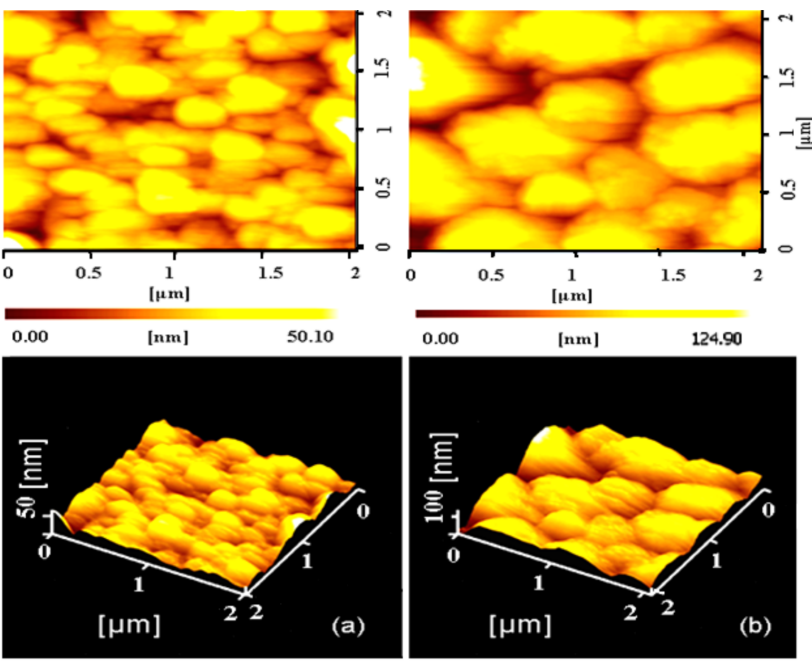

Fig. 4. Surface microstructures (scan area: $2 \mu \mathrm{m} \times$ $2 \mu \mathrm{m}$ ) obtained through AFM analysis from $\mathrm{Ag}_{2} \mathrm{Cu}_{2} \mathrm{O}_{3}$ films: (a) deposited at $T_{\mathrm{s}}=423 \mathrm{~K}$ and (b) deposited at $T_{\mathrm{s}}=423 \mathrm{~K}$ and post-annealed at $498 \mathrm{~K}$.

ing at $498 \mathrm{~K}$ showed large size grains size of which are ranging about $280 \mathrm{~nm}$, which has understandably increased the $R_{\text {rms }}$ to $\approx 28 \mathrm{~nm}$ as shown in Fig. 4 .

The electrical resistivity $(\rho)$ of the films deposited on glass substrates meanly depends on the deposition temperature. The $\rho$ of the films deposited at $303 \mathrm{~K}$ was very low, measuring about $1.2 \times 10^{-5} \Omega \mathrm{cm}$, whereas the $\rho$ has been increased with the increase in $T_{\mathrm{s}}$ to reach a value of $9.5 \times 10^{-3} \Omega \mathrm{cm}$ at $423 \mathrm{~K}$. The observed low electrical resistivity at $303 \mathrm{~K}$ may be due to the presence of ternary phase along with elemental silver. The films deposited at high $T_{\mathrm{s}}$ of $523 \mathrm{~K}$ show $\rho$ of $5 \times 10^{-5} \Omega \mathrm{cm}$, suggesting that $\rho$ is controlled by the metallic silver grains present in the films [16]. The films deposited at $423 \mathrm{~K}$ and subsequently annealed at $498 \mathrm{~K}$ showed $\rho$ of $2.2 \times 10^{-3} \Omega \mathrm{cm}$ due to improvement in the growth of single-phase $\mathrm{Ag}_{2} \mathrm{Cu}_{2} \mathrm{O}_{3}$. Petitjean et al. [8] achieved an electrical resistivity of $3 \times 10^{-3} \Omega \mathrm{cm}$ from the pulsed DC magnetron sputtered films deposited at room temperature followed by air annealing at $473 \mathrm{~K}$.

\section{Conclusions}

$\mathrm{Ag}_{2} \mathrm{Cu}_{2} \mathrm{O}_{3}$ were deposited on glass and silicon substrates using RF reactive magnetron sputtering of metallic equimolar $\mathrm{Ag}_{50} \mathrm{Cu}_{50}$ alloy target at various substrate temperature $\left(T_{\mathrm{s}}\right)$ ranging between $303 \mathrm{~K}$ and $523 \mathrm{~K}$, with an oxygen partial pressure of $2 \times 10^{-2} \mathrm{~Pa}$ and a sputtering pressure of $4 \mathrm{~Pa}$. The influence of $T_{\mathrm{s}}$ on the core level binding energies, crystallographic structure and electrical properties of the deposited films was studied. The films deposited at $303 \mathrm{~K}$ were amorphous. The films deposited at $423 \mathrm{~K}$ were of $\mathrm{Ag}_{2} \mathrm{Cu}_{2} \mathrm{O}_{3}$ phase with a fraction of $\mathrm{Ag}_{2} \mathrm{Cu}_{2} \mathrm{O}_{4}$. The films deposited at $423 \mathrm{~K}$ followed by an air annealing at $498 \mathrm{~K}$ were of single phase $\mathrm{Ag}_{2} \mathrm{Cu}_{2} \mathrm{O}_{3}$. The crystallite size of the films is increased from 12 to $20 \mathrm{~nm}$ for the increase in $T_{\mathrm{s}}$ from 303 to $423 \mathrm{~K}$, while those annealed at $498 \mathrm{~K}$ showed an enhancement in the crystallite size to $24 \mathrm{~nm}$. The electrical resistivity of the films is decreased with the increase of $T_{\mathrm{s}}$, which was controlled by the presence of silver and silver oxide phase in $\mathrm{Ag}_{2} \mathrm{Cu}_{2} \mathrm{O}_{3}$. The electrical resistivity of the films annealed at $498 \mathrm{~K}$ was $2.2 \times 10^{-3} \Omega \mathrm{cm}$.

\section{References}

[1] P. Gomez-Romero, E.M. Tejada-Rosales, M. Rosa-Palacin, Angew. Chem. Int. Ed. 38, 524 (1999).

[2] D. Munoz-Rojas, J. Fraxedas, P. Gomez-Romero, N. Casan-Pastor, J. Solid State Chem. 178, 295 (2005).

[3] D. Munoz-Rojas, Mater. Today 14, 119 (2011).

[4] C.D. May, J.T. Vaughey, Electrochem. Commun. 6, 1075 (2004).

[5] J. Feng, B. Xiao, J.C. Chen, C.T. Zhou, Y.P. Du, R. Zhou, Solid State Commun. 149, 1569 (2009).

[6] J.F. Pierson, D. Wiederkehr, J.M. Chappe, N. Martin, Appl. Surf. Sci. 253, 484 (2006).

[7] C. Petitjean, D. Horwat, J.F. Pierson, Appl. Surf. Sci. 255, 7700 (2009).

[8] C. Petitjean, D. Horwat, J.F. Pierson, J. Phys. D, Appl. Phys. 42, 025304 (2009).

[9] S. Uthanna, M. Hari Prasad Reddy, P. Boulet, C. Petitjean, J.F. Pierson, Phys. Status Solidi A 207, 1655 (2010).

[10] P. Narayana Reddy, A. Sreedhar, M. Hari Prasad Reddy, S. Uthanna, J.F. Pierson, J. Nanotechnology, 2011, article ID 986021, doi: 10.1155/2011/986021.

[11] D. Munoz Rojas, J. Oro, P. Gomez-Romero, J. Fraxedas, N. Casan-Pastor, Electrochem. Commun. 4, 684 (2002).

[12] ICDD-International centre for diffraction data, ICCD card no. 01-073-6753.

[13] ICDD-International centre for diffraction data, ICCD card no. 00-41-1104.

[14] ICDD-International centre for diffraction data, ICCD card no. 01-071-6397.

[15] ICDD-International centre for diffraction data, ICCD card no. 01-070-9128.

[16] M.T.S. Nair, L. Guerrero, O.L. Arenas, P.K. Nair, Appl. Surf. Sci. 150, 143 (1999). 